TITLE:

Development of a stent capable of the controlled release of basic fibroblast growth factor and argatroban to treat cerebral aneurysms : In vitro experiment and evaluation in a rabbit aneurysm model(Abstract_要旨)

\title{
$\operatorname{AUTHOR}(\mathrm{S})$ :
}

\section{Arai, Daisuke}

\section{CITATION:}

Arai, Daisuke. Development of a stent capable of the controlled release of basic fibroblast growth factor and argatroban to treat cerebral aneurysms: In vitro experiment and evaluation in a rabbit aneurysm model. 京都大学, 2019, 博士(医学)

ISSUE DATE:

2019-09-24

URL:

https://doi.org/10.14989/doctor.k22037

RIGHT:

学位規則第9条第2項により要約公開 


\begin{tabular}{|c|c|c|c|}
\hline & & & \\
\hline & \multicolumn{3}{|c|}{$\begin{array}{l}\text { Development of a stent capable of the controlled release of basic } \\
\text { fibroblast growth factor and argatroban to treat cerebral aneurysms: } \\
\text { In vitro experiment and evaluation in a rabbit aneurysm model } \\
\text { (basic fibroblast growth factor 及びアルガトロバンの徐放作用を有する } \\
\text { 脳動脈瘤治療用ステントの開発 : In vitro 研究とウサキ動脈瘤モデルでの } \\
\text { 評価) }\end{array}$} \\
\hline \multicolumn{4}{|c|}{ 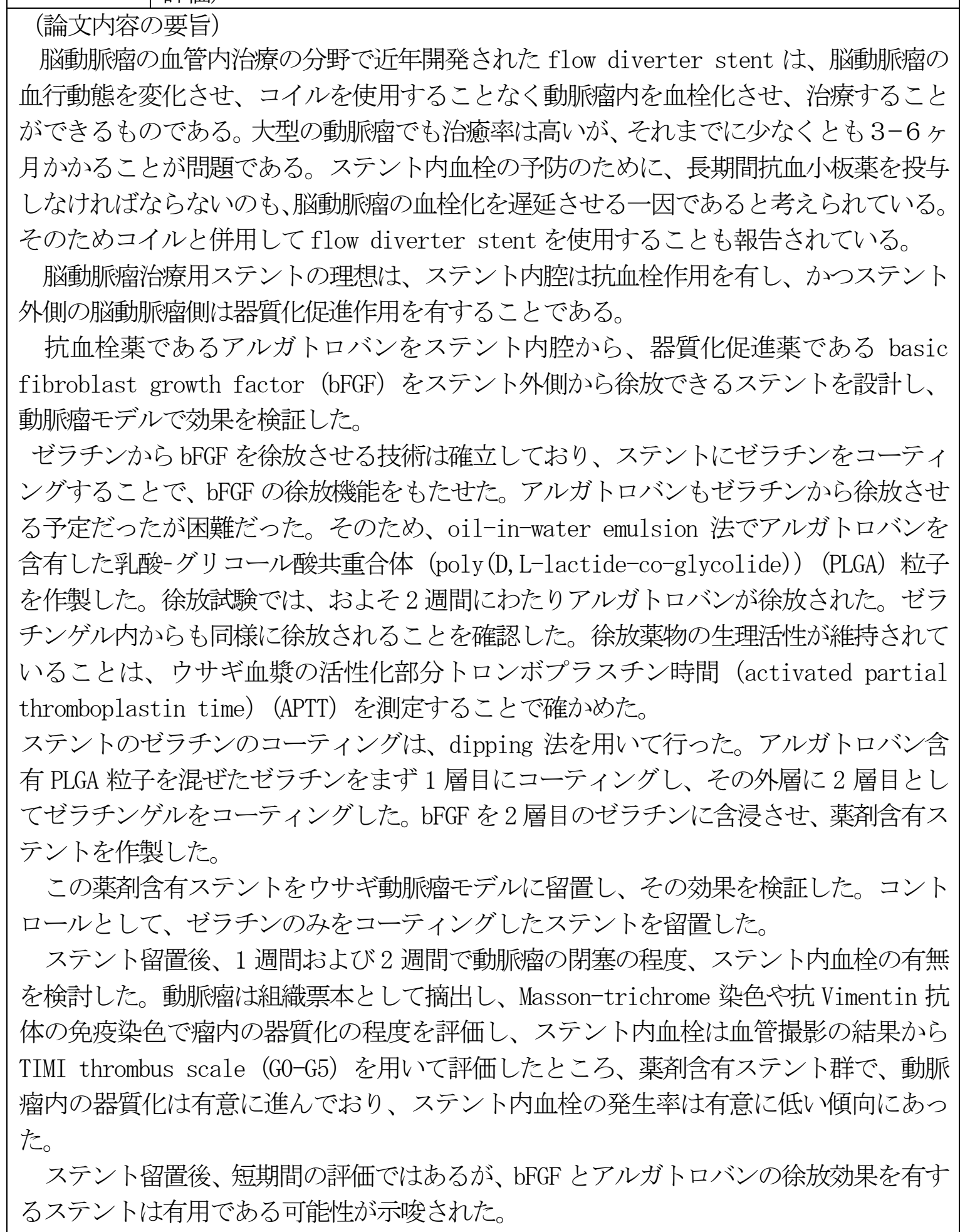 } \\
\hline
\end{tabular}

（論文審査の結果の要旨）

脳動脈瘤治療用ステントの理想は、ステント内腔は抗血栓作用を有し、かつステン 卜外側の脳動脈瘤側は器質化促進作用を有することである。

抗血栓薬であるアルガトロバンをステント内腔から、器質化促進薬である basic fibroblast growth factor (bFGF) をステント外側から徐放できるステントを設計し、 動脈瘤モデルで効果を検証した。

oil-in-water emulsion 法でアルガトロバンを含有した乳酸-グリコール酸共重合体 (poly(D, L-lactide-co-glycolide) )（PLGA）粒子を作製した。ステントのゼラチンのコ 一ティングは、dipping 法を用いて行った。アルガトロバン含有PLGA 粒子を混ぜたゼラ チンをまず 1 層目にコーティングし、その外層に 2 層目としてゼラチンゲルをコーティ ングした。bFGF 2 層目のゼラチンに含浸させ、薬剤含有ステントを作製した。この薬 剤含有ステントをウサギ動脈瘤モデルに留置し、その効果を検証した。コントロールと して、ゼラチンのみをコーティングしたステントを留置した。

ステント留置後、1 週間および 2 週間で動脈瘤の閉塞の程度、ステント内血栓の有無 を検討した。薬剤含有ステント群で、動脈瘤内の器質化は有意に進んでおり、ステント 内血栓の発生率は有意に低い傾向にあった。

ステント留置後、短期間の評価ではあるが、bFGF とアルガトロバンの徐放効果を有す るステントは有用である可能性が示唆された。

以上の研究は薬剂含有脳動脈瘤治療用ステントの開発及び有効性の解明に貢献し脳 動脈瘤に対する血管内治療の発展に寄与するところが多い。

したがって、本論文愽士（医学 ）の学位論文として価值あるものと認める。

なお、本学位授与申請者は、令和元年 6 月 12 日実施の論文内容とそれに関連した 試問を受け、合格と認められたものである。 